Pamiętnik Literacki 2021,1 , s. 75-88

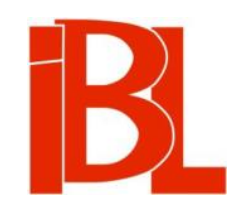

\title{
Albo słowo, albo ciało. Kreacyjna dialektyka w trzeciej części ,Traktatu o manekinach" Brunona Schulza
}

\author{
Marcin Całbecki
}


Pamiętnik Literacki CXII, 2021, z. 1, PL ISSN 0031-0514

DOI: $10.18318 / \mathrm{pl} .2021 .1 .5$

MARCIN CAŁBECKI Uniwersytet Gdański

\section{ALBO SŁOWO, ALBO CIAŁO KREACYJNA DIALEKTYKA W TRZECIEJ CZEŚCI „TRAKTATU O MANEKINACH” BRUNONA SCHULZA}

Logiczna opozycja: kobieta-mężczyzna, leży, jak sądzę, u podstaw antynomii między porządkami matriarchalnym i patriarchalnym, rozwijanej zarówno w antyku, jak i w czasach nowożytnych ${ }^{1}$. $Z$ pozoru modernistyczny mit femme fatale ${ }^{2}$, który w pisarstwie i dziełach plastycznych Schulza nakłada się na jego prywatne, seksualne fiksacje, w cyklu moich interpretacji jawi się jako jeden $\mathrm{z}$ biegunów kluczowego sporu dotyczącego porządków władzy i kultu. Pisarz zdaje się stawiać pytanie: czy centralną postacią wspólnoty - tak w wymiarze realnym, jak i wyobrażonym - jest kobieta czy mężczyzna, matka czy ojciec? Moje odczytania kolejnych opowiadań ze zbioru Sklepy cynamonowe odsłaniają wyraźnie rysujący się w tekstach Schulza konflikt między przedustawnym, naturalnym porządkiem władzy kobiet a późniejszym, nastawionym na konfrontację z tym ładem, „kacerskim” - jak nazwałby to sam autor Sanatorium pod Klepsydra - dominium ojca ${ }^{3}$. Jednym z etapów przygotowywanej przez Jakuba rebelii jest snucie przez niego quasi-naukowej opowieści, przedstawionej w trzech częściach Traktatu o manekinach. Niniejszy szkic jest interpretacją ostatniej odsłony tryptyku.

Końcowa oracja ojca zdaje się stanowić fundament teoretyczny wszystkich aktywności ojca, którego obsesja jest tworzenie, dawanie życia. Pamiętamy, że

1 Źródłem i podstawową inspiracją w snuciu przeze mnie tego antropologicznego wątku jest oczywiście kanoniczne dzieło poświęcone teorii matriarchatu w świecie greckim, czyli Matriarchat. Studium na temat ginajkokracji świata starożytnego podług natury religijnej i prawnej (Przeł. R. Re s z k e. Warszawa 2007) J. J. B a c h of ena.

2 W tym duchu - wizji kobiecości jako numinotycznej potęgi będącej zarazem źródłem męskiego lęku - dzieła B. Schulza czytają E. K u rylu k (Gasienicowy powóz, czyli podróż Brunona Schulza $w$ przyszłość przeszłości. W zb.: Bruno Schulz: in memoriam. 1892-1942. Red. M. Kitow s ka - Łys ia k. Lublin 1994) i K. Kulig - J a n a r ek (Erotyka, groteska, ironia, kreacja. W zb.: jw.).

3 Swoje interpretacje opowiadań Schulza, w których centralne miejsce zajmuje problem konfliktu porządków matriarchalnego i patriarchalnego, zamieściłem w następujących szkicach: Drohobycki matriarchat. Antropologiczne watki „Sklepów cynamonowych” Brunona Schulza. „Schulz / Forum” 2015, z. 5; Metafizyczna misja. Ojciec i próba statuowania patriarchalnego porzadku w „Sklepach cynamonowych” Brunona Schulza. „Annales Universitatis Paedagogicae Cracoviensis. Studia de Cultura” 2018; Powtórna rebelia ojca. O ciagu dalszym „Traktatu o manekinach” Brunona Schulza. „Schulz / Forum” 2018, z. 12; Ojciec $i$ Wielka Kobiecość. Antropologia płci w opowiadaniu „Manekiny" Brunona Schulza. W zb.: (Nie)męskość w tekstach kultury XIX-XXI wieku. Red. B. Z wolińs k a, K. M. T o m a la. Gdańsk 2019; Zgodnie z natura, ale wbrew prawu. Kilka uwag o „Traktacie o manekinach” Brunona Schulza. „Pamiętnik Literacki” 2019, z. 1. 
Schulz postrzega je i przedstawia jako zasadniczo przypisane domenie kobiecej. W środkowej części Traktatu o manekinach autor umieścił, co prawda, obraz przemocy wpisanej w dzieło stworzenia, powiązanej z pierwiastkiem męskim, ale też, co znamienne, nazwał te poczynania „nieporozumieniami ucieleśnionymi” (S 68) ${ }^{4}$.

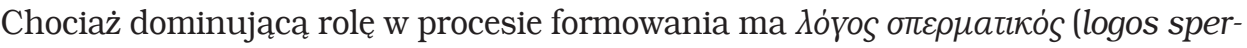
matikos) - ugruntowana na starożytnej metafizyce siła formotwórcza, którą można identyfikować $z$ męskim, patriarchalnym porządkiem - to jednak ów duchowy, formotwórczy, męski porządek, przemocą owładniający materię, oceniony zostaje przez ojca jako parodia prawdziwego gestu twórczego. Nieprzypadkowo pierwsze zdanie ostatniej części Traktatu, wypowiedziane przez Jakuba, przynosi wezwanie do odwrócenia opisów z części środkowej i do zaprzeczenia przyjętego wcześniej sposobu myślenia o tworzeniu:

Nie o tych nieporozumieniach ucieleśnionych, nie o tych smutnych parodiach, moje panie, owocach prostackiej i wulgarnej niepowściągliwości - chciałem mówić, zapowiadając [...] rzecz o manekinach. Miałem na myśli coś innego. [S 68]

Komentarz ten znamiennie definiuje formę owych wcześniejszych wystąpień. Określone zostają jako improwizacje, pełne uniesienia perory snute przez ojca kierowanego jakąś tajemniczą siłą. Widać, że nie daje się ona całkowicie kontrolować, skoro spójność narracji naruszają liczne dygresje, które po wygłoszeniu mówca zaczyna traktować jako marginalne albo nieistotne. Być może, towarzyszące mu zażenowanie wiąże się z przekonaniem, że wypowiedział jakąś tajemnicę, która winna pozostać w ukryciu. Należy bowiem pamiętać, iż ojciec kokietuje i prowokuje swego „arcywroga” 5 , czyli Adelę i jej pomocnice. Faktycznie „ciąg dalszy” zdaje się stanowić wizję męskiej rebelii wznieconej po to, by podporządkować sobie materię rozumianą w sposób żeński. Przypuszczalnie obraz konfliktu płci opiera się w opowiadaniach Schulza na koncepcjach ugruntowanych w dwuwartościowej logice. Owocem ustanowionego przez Arystotelesa i jego uczniów porządku myśli są licznie występujące w zachodniej filozofii koncepcje binarne, choćby te opisujące byt jako złożony z materii i formy. Zdaniem ojca, owa opozycja stanowi jeden z przykładów wspomnianych wcześniej „nieporozumień ucieleśnionych”, w tym przypadku polegających na narzuceniu przemocą męskiej, metafizycznej, duchowej formy - kobiecej materii, ciału i naturze. Nazwanie takiego aktu w pierwszej części Traktatu „gwałtem” najwymowniej świadczy, że światem przedstawionym Schulza rządzi konflikt, co poniekąd potwierdza tezę Michała Pawła Markowskiego o heglowskich inklinacjach tej prozy ${ }^{6}$. Spór ten w swej istocie dotyczy także konfliktu płci. To właśnie taki rodzaj agonicznego splotu jako pierwszy zaobserwował i omówił Johann Jakob Bachofen, wskazujac na pierwotną dominacje kobiet, która scharakteryzował w opowiadaniu Sierpień.

4 Skrótem S odsyłam do: B. Schulz, Sklepy cynamonowe. W: Proza. Wyd. 2. Przedm. A. S a nd a u e r: Rzeczywistość zdegradowana. Kraków 1973. Liczby po skrócie oznaczają stronice.

5 Formułą tą B. S chulz (Exposé o ksiażce Brunona Schulza „Sklepy cynamonowe”. W: Księga listów. Zebrał, oprac., wstępem, przypisami i aneksem opatrzył J. F i c o w s k i. Kraków 1975, s. 178) określa funkcję Adeli w narracji Sklepów cynamonowych.

6 M. P. Markow s ki, Powszechna rozwiąłość. Schulz, egzystencja, literatura. Kraków 2012. 
Wspomniana konfrontacyjna relacja, rozpisana na wiele szczegółowych zdarzeń w świecie przedstawionym Sklepów cynamonowych, ogniskuje się wokół stanu „nieporozumienia” (S 68). To w związku z ową rozbieżnością ujawniają się mecha-

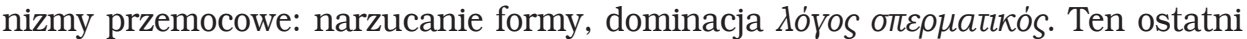
termin filozoficzny w dziele Schulza koresponduje z kluczową dla rozważań nad trzecią częścią Traktatu o manekinach idea „generatio aequivoca” (S 68). Pisarz przywołuje ja, by określić siły, które przemoca podporządkowuja sobie kobieca materię. Wiele sformułowań pozwala zobaczyć w nich źródło nadużyć seksualnych nazwanych nieprzypadkowo „owocami prostackiej i wulgarnej niepowściągliwości” (S 68). Warto zaznaczyć, iż w określeniu tym dochodzi do radykalnego odwrócenia tradycyjnego wartościowania relacji materia-forma. Relacji, która w klasycznych ujęciach w tym, co materialne i cielesne, dostrzega tylko potencję, podłoże zjawisk, sens bytu wiążąc zasadniczo $\mathrm{z}$ jego formą, ze strukturalnym porządkiem, który decyduje o takim, a nie innym formalnym urzeczywistnieniu. To logiczne uformowanie bytu oceniane jest przez narratora jako „prostackie i wulgarne” oraz niepowściągliwe. Ciekawe, że Schulz tradycję europejskiej ontologii opisuje językiem społecznych konwenansów tak, jakby zachowanie opresyjnego mężczyzny było ucieleśnieniem autorytarnych ciagot zachodniej metafizyki. U Schulza wielokrotnie zostaje zarysowana ta osobliwa analogia, co do której sam narrator odnosi się jednak z ironią. Jest to bowiem także „smutna parodia” (S 68). Konstatacja dotycząca związku między tym, co akademickie, uświęcone i poważne, a tym, co banalne, śmieszne i pospolite, stanowi poniekąd znak rozpoznawczy Schulzowskiej filozofii, potwierdzonej przez zaskakujące urzeczywistnienie idei Księgi.

W wykładach ojca podobny dualizm również się ujawnia, choć wątek ten odnajdujemy tylko na marginesie rozważań Jakuba. W Dokończeniu tematem kluczowym jest męskie tworzenie. Można też powiedzieć, że wszystkie pragnienia i działania ojca przedstawiane w Sklepach cynamonowych wiążą się z tym zagadnieniem. Jakub owładnięty zostaje obsesją męskiego stworzenia, patriarchalnego ustanowienia życia, które według Ericha Fromma jest osią biblijnej Księgi Rodzaju:

Przyjrzyjmy się skrajnie męskiemu charakterowi starotestamentowej relacji. Pierwszym aktem stworzenia jest narodzenie światłości. Światło zawsze i wszędzie jest symbolem męskiej zasady, trudno się więc dziwić, że również w biblijnej relacji o stworzeniu światło jest początkiem świata?

Do tej kreacji zapisanej w Biblii Schulz bez wątpienia nawiązuje, co w oczywisty sposób potwierdza podtytuł Traktatu o manekinach, a mianowicie Wtóra Księga Rodzaju.

Samo Dokończenie wydaje się najmniej spójną częścią Traktatu. Rozpoczyna je opis pseudofauny. Następnie narrator skupia swoją uwagę na zaskakującej kreacji zrodzonej ze stanu nudy. Kolejny fragment wyjaśnia „konflikt serologiczny” drzewa (jest to bardzo istotny passus, wskazujacy na starogreckie i filozoficzne rozumienie pojęcia materii). Wykład kończy zarysowany przewrotnie wątek antropocentryczny. Choć jego centralną tezę stanowi afirmacja panwitalizmu, to jednak wychwalana

7 E. Fromm, Miłość, płeć i matriarchat. Przeł. B. Radomska, G. Sowiński. Wyd. 2, popr. Poznań 1999, s. 63. 
żywotność wiąże się z degradacją człowieka, ponieważ zrównuje kondycję ludzką ze sposobami istnienia obiektów przyrody uznawanej za nieożywioną.

Poszczególne fragmenty wykładu mają charakter luźnych wariacji na temat materii i wpisanej w nią kategorii życia. Nie łączą się ze sobą ściśle i nie wynikają z siebie. Nie powinno to jednak dziwić. Konwencja, w jakiej zaprezentowano tyrady ojca, wskazuje na to, że ów retor przedstawił swe tezy w sposób nie do końca uporządkowany, improwizując i popadając w sprzeczności. Ten element chaosu najwyraźniej dochodzi do głosu właśnie w części trzeciej. Żeby mu się przyjrzeć, postanowiłem podzielić swój wywód na cztery segmenty zgodnie ze schematem, o którym wcześniej wspomniałem.

\section{"Generatio aequivoca"}

„Generatio aequivoca” jest to termin, który budzi namysł wielu schulzologów. Wśród nich najskrupulatniej dzieło Schulza czyta chyba Jerzy Jarzębski, łącząc próby ujęć bardziej syntetycznych z nie kończącymi się „Przypisami Schulza”. To owa literalnie pojmowana hermeneutyka ukierunkowana na wyjaśnienie miejsc zagmatwanych przyświeca pracy tego literaturoznawcy. $Z$ poczucia słuszności takiego postępowania wypływa też moja potrzeba kontekstualizacji odczytań Schulza według klucza konfliktu płci. Kierunek owego ujęcia wskazuje właśnie Jarzębski, gdy interpretujac Traktat o manekinach, tak silnie zwraca uwage na problem kontaminacji dualizmu płci, a także odwołuje się do klasycznego, filozoficznego podziału na materię i formę ${ }^{9}$. To ostatnie rozróżnienie wyraża finalnie w duchu teologicznym, łączac $z$ kategoria grzeszności. Moje odczytania idą faktycznie tym tropem (choć zawieszają wykładnię w świetle teologii). Niniejszy artykuł można odebrać jako swoisty przypis do przypisu Jarzębskiego, który w edycji „Biblioteki Narodowej” wskazuje na znaczenie Schopenhauerowskiego kontekstu, szczególnie dotyczy to uwag filozofa zawartych w Metafizyce miłości płciowej. Zarazem termin „generatio aequivoca” komentator i wydawca Schulza tłumaczy jako „samorództwo” 10 . Sądzę, że warto postawić tu pytanie, na ile kwestia partenogenezy i wolicjonalnego wymiaru funkcjonowania świata - stanowiące clou odwołań do filozofii Arthura Schopenhauera - miałyby się w prozie autora Sklepów cynamonowych realizować. W istocie sprawa samorództwa jest dla artysty bardzo istotna, co uzmysławia choćby specyfika opisu ciotki Agaty, zawartego w pierwszym opowiadaniu zbioru. Schulz powiela w nim archaiczny i zakorzeniony w świecie cywilizacji matriarchalnej system myślenia o rozmnażaniu, do którego zdolne są wyłącznie kobiety. O ciotce Agacie pisarz mówi: „Była to płodność niemal samoródcza [...]” (S 43). Także w ostatniej części Traktatu powraca temat partenogenezy, choć trzeba pamiętać, że to powtór-

Zob. J. J a r z ę b s k i, Powieść jako autokreacja. Kraków 1984, s. 213: „Ukazaną tu Itj. w Traktacie o manekinach] opozycję ducha i materii można dalej rozwijać, kojarząc ducha z pierwiastkiem męskim, materię - z żeńskim. Pierwszy wcielałby ideę formotwórczą, niejako abstrakcyjną, drugi fizyczną inkarnację, obciążoną u zarania grzechem cielesności”.

10 Zob. B. Schulz, Opowiadania. - Wybór esejów i listów. Oprac. J. J a rz ę b s ki. Wyd. 2, przejrz. i popr. Wrocław 1998, s. 43, przypis 1. BN I 264. 
ne przywołanie jest przywołaniem z różnica. Dotyczy bowiem, by tak rzec, ojcowskiej wersji partenogenezy. Jest reinterpretacją klasycznego ujęcia. Co więcej, reinterpretacją dokonywaną $\mathrm{w}$ duchu polemicznym wobec dziewiczych narodzin $\mathrm{z}$ ciotki Agaty.

Zgodnie z systemem wierzeń matriarchatu kobiety rodzą bez udziału mężczyzn, dlatego wydają się święte i są czczone jako istoty w szczególny sposób obdarowane. Ten stan rzeczy nakreślony zostaje najwyraźniej w inicjalnym opowiadaniu tomu Sklepy cynamonowe. Potem jednak następuje rebelia męska, opisana najsugestywniej w utworze Ptaki, zawierającym charakterystykę męskiego, ojcowskiego aktu kreacji. Aktu, dodajmy, nieudanego. Jakub ponosi klęskę, udaje się do Canossy, wychwalając manekina w pierwszej części Traktatu, który w opowiadaniu poprzedzającym został nazwany „kobiecym molochem” oraz „milczącym idolem” (S 58). Po tym momencie „poddania” ojciec jednak ponawia próbę. W drugiej części wykładu, świadomie przez Schulza wyodrębnionej jako „ciag dalszy”, dostrzegamy coś w rodzaju gry ojca, zmierzającej ku restauracji patriarchalnego wzorca, ujmowanego w duchu tradycyjnej zachodniej metafizyki jako ciagg następujących pojęć: metafizyka - logos - forma - mężczyzna. Ten, jeśli można tak powiedzieć, pojęciowy kwartet wyraża porządek, według którego ojciec próbuje przemocą podporządkować sobie „po kobiecemu plastyczną materię” (S 62). Widzimy zatem, że w drugiej części Traktatu dokonuje się zmiana czynnika dominującego, który przybiera tradycyjne, męskie formy. Równocześnie mamy tu ciagle dwudzielną wizję świata, która opiera się w istocie na dwuwartościowej logice Arystotelesa. Ojciec poniekąd ją reprodukuje, nadając szczególny, związany z płcią rys. Ostatnia część Traktatu przynosi - o czym była już mowa - koncepcje „generatio aequivoca”. To trzecia, dla ojca kluczowa, koncepcja: męskiego, samodzielnego dzieworództwa. Możemy więc zauważyć, że trzy części traktatu układają się w logiczny ciag przedstawień. Rozpoczyna go - w ramach captatio benevolentiae, czyli zapewnienia sobie życzliwości słuchaczek - apoteoza materialnego, kobiecego stworzenia. W drugiej partii pojawia się ujęcie dialektyczne, podkreślające zależność: pan-sługa (forma-materia). Rela-

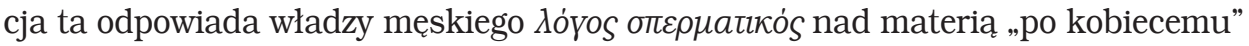
plastyczną. Męski porządek zdaje się już tutaj dominować, lecz wciąż nadbudowany zostaje nad niższą, materialną bezforemnością. Ten drugi obraz prowadzi jednak definitywnie do pełnego wyzwolenia męskiej siły i do fantazmatu męskiego dzieworództwa, o którym czytamy w ostatniej części Traktatu o manekinach. Wszakże Fromm stawia tę sprawe jasno:

Myśl, że jedynie mężczyzna może swoimi ustami, swym słowem, ze swego ducha stworzyć żywą istotę, jest urojeniem, które pozostaje w największej sprzeczności z naturą, neguje wszelkie doświadczenie, wszelką rzeczywistość, wszelkie uwarunkowania naturalne ${ }^{11}$.

Co bowiem w swej istocie znaczy „generatio aequivoca”?

Termin ten nawiązuje do podtytułu traktatu i jest poniekąd jego łacińską parafraza. Oto Genesis - Ksiega Rodzaju, i "generatio" to słowa sobie pokrewne. Co ważne, w Słowniku łacińsko-polskim pod redakcją Mariana Plezi znajdujemy na wstępie takie znaczenie „generatio”: „(u mężczyzn) zdolność płodzenia”. Dopiero 
kolejne definicje podają: „2. (u kobiet) płodność, 3. (u zwierząt) siła rozrodcza”12. Zatem w istocie termin "generatio" dotyczy kluczowej ojcowskiej obsesji, która w badaniach antropologów uznawana jest za najważniejszy wyznacznik podziału na zamierzchły system matriarchalny i następujący po nim patriarchat. Fromm mówi wprost - mężczyzna mógł zdominować społeczeństwo, jeśli był w stanie wykazać, że dysponuje zdolnością do kreacji, że dane mu jest to wszystko, co zawiera się w terminie "generatio". Tu kryje się źródło obsesji ojca. Jego ptasia impreza stanowi przykład takiej męskiej kreacji, której nie chce i nie może zaakceptować Adela. Nie mam wątpliwości, że w momencie, gdy ojciec powraca w swoich wywodach do kwestii męskiego płodzenia, chodzi tu o taką alternatywną, sprzeczną z natura, wynaturzoną właśnie dlatego, iż męską - kreację. O tym świadczy epitet towarzyszacy terminowi "generatio". „Aequivoca” to „dwuznaczny”" ${ }^{13}$. Schulz decydując się na to określenie, akcentuje dwuznaczność męskiej płodności, która jest czymś więcej niż tylko płodzeniem - ma charakter kreacji pierwotnej. W tym duchu w Sklepach cynamonowych objawia się ojciec jako dawca wszelkiego życia. Widzimy zatem, że między "generatio aequivoca” a Wtóra Księga Rodzaju, „Wtórą Genesis” istnieje zależność - związek opierający się na tworzeniu alternatywnego projektu, pierwotnego wobec naturalnego łańcucha dawania życia. Jak owo życie jest przekazywane, czym się charakteryzuje, o tym dowiadujemy się z kolejnych fragmentów trzeciej części Traktatu. Ojciec opowiada w niej swym słuchaczkom o kacerskich, alternatywnych, dwuznacznych formach życia. Widać wyraźnie, że w każdym zbliżeniu, kadrze, przykładzie przedstawiany przez ojca projekt ma charakter sprzeczny $z$ porządkiem naturalnym. Wizja męskiego stworzenia - męska ciąża - jawi się jako ze wszech miar nienaturalna, przeciwstawiająca się biologii i tzw. zdrowemu rozsądkowi. Mimo to ojciec nie ustaje w admiracji swojej wizji, co potwierdzają trzy kolejne, luźno ze sobą związane opowieści o alternatywnym, dwuznacznym życiu. W pierwszej odsłonie dowiadujemy się o „pokoleniu istot na wpół tylko organicznych” - „pseudowegetacji” i „pseudoflorze” (S 68) - stanowiących efekt fantastycznej fermentacji materii.

\section{Fantastyczna fermentacja materii}

Początkowo ojciec skupia swą uwagę na fermentacji materii - to ona jest źródłem owych osobliwych „na wpół tylko organicznych” obiektów. Trudno powiedzieć, na ile wykładowca świadomie operuje specjalistyczną terminologią, która potwierdzać by mogła posiadanie przez niego wiedzy $\mathrm{z}$ zakresu chemii, a na ile jest to jedynie zabieg retora chcącego pozorami politechnicznego wykształcenia przytłoczyć szwaczki i służąca. Niewątpliwie odwołując się do terminu „fermentacja”, rozumianego jako proces pomnażania energii, jako „forma metabolizmu drobnoustrojów, służąca do zaopatrzenia tych organizmów w energię niezbędną do procesów życiowych"14, ojciec chce uspokoić słuchaczki i zapewnić je, że wszystkim tym płodnym ekscesom pa-

14 Fermentacja. Hasło w: Chemia. Encyklopedia szkolna. Red. W. B a t u r o. Warszawa 2001, s. 209. 
tronuje Bóg, w którego wierzą słuchaczki i który jest szczególnie bliski Menadzie Adeli. Bogiem życia powierzającym ludziom tajemnice procesu fermentacji był - jak pamiętamy - Dionizos. O tym greckim patronie winorośli Bachofen pisze: ,jest w najpełniejszym znaczeniu tego słowa bogiem kobiet"15. Według przekazów mitycznych Dionizos był bogiem, który nauczył ludzi procesu fermentacji. Jej tajemnica polega na pomnażaniu energii, a nie materii. Czego wynikiem było z kolei pojawienie się pseudofauny. Można by rzec, że ojciec podczas wygłaszania swej mowy opisuje obiekty rodzące się w dionizyjskim szale. Ów trans, w który wprawiła się Adela przyrównana do Menady, fascynuje też Jakuba. Być może, w jego koncepcji tajemnica dionizyjskiego szału jest w istocie analogiczna do tajników procesu kreacji. Tę ewolucję mitu stwarzania zobrazował także przywołany już Bachofen, według którego Dionizos, podobnie jak kobiece Demeter (Ceres) czy Pomona, to bóg płodności:

Symbole cerealnego macierzyństwa, kłosa i chleba, ustępują miejsca bachicznej winorośli, bujnemu owocowi bogatego w siłę rozrodczą bóstwa, mleko, miód i woda, czyste ofiary dawnych czasów, ustępują ekstatycznemu, budzącemu nieokiełznanie rozkoszy zmysłowej winu, w kulcie zaś religia najgłębszego telluryzmu, płodzenie w błotnej wilgoci wraz ze wszystkimi jego wytworami, zwierzętami i roślinami zdobywa znaczną przewagę nad bardziej zaawansowaną kulturą rolniczą oraz jej owocami ${ }^{16}$.

Ową dwuznaczność płodności widać wyraźnie w idei dionizyjskiej fermentacji winorośli. Porządek kreacji nosi przecież znamiona niszczenia. Ojciec ma świadomość owej destrukcyjnej mocy bachicznej ekstazy. Mówi o tym w pierwszej części Traktatu o manekinach, dokonując apologii zbrodni wpisanej w akt stworzenia. Ten ambiwalentny wątek jednoczesnej kreacji i zniszczenia jest głęboko osadzony w rycie dionizyjskim. Karl Kerényi ową dwuznaczność fermentacji komentuje następująco:

Owoce słodkie rodzi winna latorośl, zdolna dzięki swemu powolnemu, samochwytnemu wzrostowi rozpościerać wokoło wielki spokój, ale również budzić - swym szybko fermentującym sokiem - ogromny niepokój, rozpalać i intensyfikować życie do takiego stopnia, że istoty ożywione mogą wzajem zadawać sobie śmierć, a więc coś z życiem najbardziej sprzecznego i nie do pogodzenia ${ }^{17}$.

Warto zauważyć, że w opisie pseudofauny ojciec konsekwentnie podkreśla niematerialność tworów fermentacji. Wykorzystując dość specjalistyczną wiedzę chemiczną, sugeruje, że te dziwne okazy pozbawione są wszystkiego, co świadczyć by mogło o materialnym charakterze pojawiających się istot (,analiza chemiczna nie wykazywała w nich nawet śladu połączeń białkowych ani w ogóle związków węgla”, S 68). Nie są to zatem organizmy w sensie biologicznym, nie dysponują tym, co w narracji Schulza stanowi rozpoznawalny znak kreacji kobiecej: wyzbyte sa ciała, mięsa. Ta desomatyzcja kreacji alternatywnej, którą tak wychwala ojciec, każe przypuszczać, że w przywoływanym fragmencie Jakub nadal snuje wizję męskiego płodzenia. Jak podaja antropologowie, u jej sedna tkwi przewartościowanie kluczowych wyobrażeń kultury, operującej opozycjami ciała i ducha, ciału przypisujacej rodzenie, a tworzenie niematerialnemu słowu.

Widziane z perspektywy antynomii między tym, co kobiece, czyli zgodne z po-

Ibidem, s. 37.

17 K. Ke rény i, Dionizos. Archetyp życia niezniszczalnego. Przeł. I. Ka ni a. Warszawa 2008, s. 71. 
rządkiem natury, a tym, co męskie, czyli owocujące nienaturalnymi tworami pseudofauny, efekty fermentacji sytuują się po męskiej stronie. Są one bowiem tworami niematerialnego, intelektualnego procesu wspominania i pamiętania, zatem tego wszystkiego, co zachowane jest w męskiej idei słowa-logosu. Akt kreacji owych istot odbywa się poprzez pamiętanie:

Były to w istocie istoty amorfne, bez wewnętrznej struktury, płody imitatywnej tendencji materii, która, obdarzona pamięcią, powtarza z przyzwyczajenia raz przyjęte kształty. [S 68]

W rzeczywistości męska kreacja dokonuje się więc poprzez przypominanie. To ojcowska pamięć jest źródłem alternatywnej, dwuznacznej kreacji, odmiennej od reprodukującego się bezmyślnie mięsa. Zatem koncepcja ojca nie tylko wprowadza do tej teorii ideę niematerialnego logosu, lecz w zasadzie sankcjonuje także porządek patriarchalny, który w historii filozofii europejskiej w największym stopniu dowartościował to, co niematerialne, duchowe, metafizyczne. Skoro pseudofauna powstaje poprzez przypominanie, to jej status jest analogiczny do sposobu istnienia Platońskich idei, które też uobecniają się w jednostkowej świadomości poprzez akt przypominania - anamnezy.

Duchowy charakter istot stworzonych w wyniku fermentacji podkreśla jeszcze wszakże ich cecha. Nie dysponują one ciałem, nie ma w nich białka ni węgla. Jedynym naturalnym procesem, jakiemu podlegaja, jest oddychanie: „U istot tak powstałych można było stwierdzić proces oddychania [...]” (S 68). Dlaczego to właśnie ten proces jest tak ważny w kreacji „generatio aequivoca”? Otóż wydaje się, że w całej koncepcji dotyczącej żywej materii właściwy jej hilozoistyczny rys wskazuje na wyraźną inspirację jońskimi filozofami przyrody ${ }^{18}$. Trzeci z presokratejskich myślicieli - Anaksymenes, był bodajże pierwszym teoretykiem istot duchowych. Utożsamiał apxí (arche) z powietrzem, uznając oddech za najbardziej namacalny

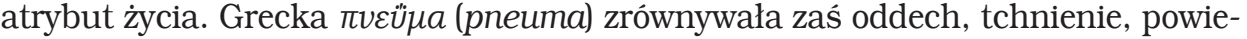
trze $z$ tym, co ludzkie, antropocentryczne, duchowe. W Collectio placitorum philosophicum Aetiusa czytamy:

Anaksymenes Milezyjczyk, syn Eurystratosa, twierdził, że początkiem wszystkiego, co istnieje, jest powietrze: $z$ niego bowiem wszystko powstaje i na nie się znowu rozpada. Podobnie jak dusza - powiada - która jest powietrzem, trzyma nas w skupieniu, tak i cały świat również otacza tchnienie i powietrze. Uważał za synonimy powietrze i tchnienie ${ }^{19}$.

Termin „hilozoizm” to kategoria filozoficzna zarezerwowana do opisu specyfiki materii. Oznacza ona przekonanie o witalistycznym charakterze wszystkiego co materialne (gr. $\ddot{u} \lambda \eta\langle h y l \bar{e}\rangle-$ materia; $\zeta \omega \dot{\eta}\langle z \bar{o} \bar{e}\rangle-\dot{z} y c i e)$. Pogląd ten bywa przypisywany myśli pierwszych europejskich filozofów - jońskich filozofów przyrody: Talesa, Anaksymandra i Anaksymenesa. Warto wspomnieć, że w innym kontekście umieszcza ów hylozoizm S. Chw in (Twórczość i autorytety. Bruno Schulz wobec romantycznych dylematów tworzenia. „Pamiętnik Literacki” 1985, z. 1), analizując opowiadania Schulza. W swojej interpretacji figury materii i materialności oraz przeciwstawianej im formie Chw in (ibidem, s. 75) odnosi się do romantycznych mitów kreacyjnych: „Ten romantyczny topos twórczości Bruno Schulz podejmie w swojej poetyckiej wizji świata, fabularyzując i personifikując antynomie związane $\mathrm{z}$ romantycznym pojmowaniem dylematów tworzenia. Antynomie te nadbudowują się nad istotną dla romantycznego światopoglądu dwuaspektowością obrazu rzeczywistości".

19 A tius, Collectio placitorum philosophicum I 3, 4. Cyt. z: Antologia tekstów filozoficznych dla 
Dwie cechy istot powstałych w aktach męskiej kreacji - ich anamnestyczne pochodzenie oraz fakt dysponowania duszą, czyli tchnieniem, uzmysławia, w którą stronę zmierza projekt Jakuba. Jest to wizja stwarzania alternatywnego wobec porządku natury, które sankcjonuje i afirmuje świat intelektu i idei. Za pomoca tych właśnie niematerialnych atrybutów męskiej kreacji ojciec próbuje zdyskredytować naturalne, kobiece, somatyczne rodzenie, którego efektem jest mięso, i zepchnąc w sferę antywartości.

\section{Pamięć a istnienie}

Środkowa część ostatniego fragmentu Traktatu zawiera wyjaśnienie, według jakich reguł dokonuje się proces ustanawiania męskiej genesis. Kluczowym punktem wykładu ojca jest stwierdzenie: „Byłem szczęśliwy [...]” (S 70). Słowa to zaskakujące, jeśli się bierze pod uwagę długie pasmo upokorzeń i nieszczęść, jakie spotykają i dotykają bohatera kolejnych opowiadań Sklepów cynamonowych. Pamięć o nich podkreśla znaczenie składanej deklaracji, a opis osobliwej wiosny u schyłku zimy, która eksploduje w zapominanych pokojach starych mieszkań, ukazuje dziwność i nienaturalność przestrzeni, w jakiej ojciec osiaga stan eudajmonii. To właśnie wykreowana jako efekt anamnezy rzeczywistość przynosi Jakubowi ukojenie. Obraz produktów fermentacji materii jest tylko wstępem:

Wszelako prymitywne te formy były niczym w porównaniu $\mathrm{z}$ bogactwem kształtów i wspaniałością pseudofauny i flory, która pojawia się niekiedy w pewnych ściśle określonych środowiskach. Środowiskami tymi są stare mieszkania, przesycone emanacjami wielu żywotów i zdarzeń - zużyte atmosfery, bogate w specyficzne ingrediencje marzeń ludzkich - rumowiska obfitujące w humus wspomnień, tęsknot, jałowej nudy. [S 68-69]

Należałoby zwrócić uwagę, w jaki sposób Schulz przedstawia antropomorficzną sferę istnienia, która wydaje $z$ siebie fantastyczne kwiaty, pseudofaunę i pseudoflorę, rodząc życie alternatywne, co uszczęśliwia ojca i pozwala mu osiagnąć spełnienie.

Życie opisywane w Sklepach cynamonowych, szczególnie w inicjalnym opowiadaniu Sierpień, które w quasi-mitycznej narracji Schulza pełni funkcję genesis, jest przesycone materialnością, mięsem, ma charakter sensualny i telluryczny. Kobiece stworzenie dokonuje się poprzez ciało i znaczy je cielesność. Zdawałoby się, że skrajny biologizm płodności kobiecej nie zostawia żadnego miejsca na sferę, która konstytuuje porządek ducha i intelektu. To czysta ९úors (physis), odsłonięta na chwilę w momencie jej największej obfitości, pełni - w samym środku lata. Termin

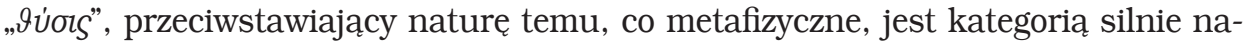
cechowaną płciowością. Nieprzypadkowo jeden z sensów tego słowa odpowiada kobiecym narządom płciowym. Termin ten oznacza „płeć” lub „narząd płciowy ([mowa] zwłaszcza o żeńskich narządach płciowych)"20.

Fragment opisujący życie już nie pulsującego ogrodu, lecz zamkniętego i zapo-

maturzystów, olimpijczyków, studentów inauczycielifilozofii. Red. nauk. M. B a r d el. Cz. 1. Kraków 2002, s. 12-13 (przeł. B. Ku pis).

20 Physis. Hasło w: Stownik grecko-polski. Red. Z. Abramowiczówna. T. 4. Warszawa 1965, s. 575. 
mnianego mieszkania u schyłku zimy, pozwala kreślić witalistyczny koncept istnienia, alternatywnego wobec znaczonego fizycznością kobiecego sposobu przekazywania życia. Kluczową rolę odgrywają tu te aspekty bytu, które w klasycznym podziale ontologicznym zaliczyć należy do istnień tylko pomyślanych. Świat kobiecy to esse reale - byty rzeczywiste, namacalne, dane jedynie sensualnemu doświadczeniu. Odrzucając je, ojciec kreśli natomiast wizję rzeczywistości złożonej z bytów

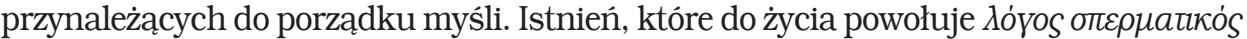
i których dominium stanowi sfera niematerialna. Można nazwać je „esse in intellectu”, są bowiem efektem pracy umysłu i ducha. Czyż nie taki właśnie charakter maja wspomnienia, tęsknoty i twory nudy.

Pseudoflorę, to puszyste kwiecie, do życia powołuje praca umysłu - גóyos, którego niezwykle ważną częścią jest proces pamiętania, źródłowy dla niematerialnego ustanowienia życia, o czym była mowa wcześniej. Wskazywaliśmy, jak istotną rolę w męskim stworzeniu świata odgrywa myśl. Życie nie potrzebuje już ciała. Wystarczy mu słowo - werbalizowane przez ojca wspomnienie i tęsknota. Właśnie aspekt przywoływania, stwarzania słowem wydaje się tu kluczowy. Marduk z eposu babilońskiego również wypowiada zaklęcie powodujące zrośnięcie się postrzępionej szaty i wszyscy uznają w nim męskiego stwórcę, który może pokonać i zastąpić matriarchalną Tiamat ${ }^{21}$. Ojciec wprawdzie nie wypowiada zaklęć, lecz praktykuje podobną, intelektualną aktywność - pogrąża się w melancholii, wspomina i tęskni, a ta czynność jest tożsama $z$ alternatywną formą płodności - męskiej, logocentrycznej, bezcielesnej.

Istnienie owego dwuznacznego, „fantastycznego” - jak nazywa go ojciec - życia opiera się zatem na anamnezie, zmierza ku światu idealnemu, bliskiemu wizji Platońskiej. Na związki projektu ojca $z$ koncepcją transcendentnych bytów wskazuje choćby sformułowanie wyjęte wprost $z$ platońskiej i neoplatońskiej doktryny. To nie przypadek, że „pseudofauna i flora” powstają jako „emanacja wielu żywotów i zdarzeń”. Terminem „emanacja” zwykło się określać status ontologiczny bytów Plotyna umieszczonych na drabinie zdematerializowanych obiektów, które w swym idealnym dążeniu do jedni przeobrażają się kolejno ze sfery materialnej w duszę i ducha, współtworzac ostatecznie absolutna jednię. Co ciekawe, w wizji ojca mamy do czynienia $z$ emanacjami żywotów i zdarzeń, tak jakby ojciec w swej wizji zamkniętego pokoju projektował wyższy, niematerialny, idealny świat, który zarazem przesycony jest witalnością i życiem par excellence. Jeśli zaś podkreślić jeszcze rolę

21 Tak zostało to ujęte w babilońskim eposie zatytułowanym Enuma Eliš, czyli Opowieść babilońska o powstaniu świata (Oprac. J. Bro m s ki. Wybór B. Be d na re k. Wrocław 1998, s. 65-67):

rozkaż, by coś uległo zniszczeniu i powstało na nowo, a to się stanie.

Otwórz swe usta, zniknie szata,

odmów, rozkaż jej, a szata będzie cała.

Rozkazał swymi usty i zniknęła szata,

odmówił, rozkazał jej, i szata powstała na nowo.

Gdy skutek jego ust ujrzeli bogowie, jego ojcowie,

ucieszyli się, oddali hołd bogu Mardukowi, królowi.

Zdaniem F r o m m a (op. cit., passim), to właśnie ten epos stanowi zapis patriarchalnej rewolucji triumfu męskiego herosa nad starym kobiecym dominium. Następnym etapem utwierdzającym panowanie męskiej zasady staje się religia czcząca Jahwe - monoteistycznego rytu osadzonego w kulcie uranicznej świętości, z jej konceptem „dalekiego boga”, który świat stwarza słowem. 
afektów, które nieodłącznie towarzyszą byciu spełniającemu się w tym zdematerializowanym alternatywnym świecie, to możemy nawet zaryzykować tezę, że wykładając Traktat o manekinach, ojciec wstępuje do idealnej, niematerialnej rzeczywistości spowitej platońskim słońcem. Zapominane mieszkanie należałoby w zasadzie traktować jako synonim nieba, „pełnego szeptów, lśnień, kołysań, jakiejś fałszywej i błogiej wiosny" (S 69), pamiętając, że niebo było już znakiem męskiego władztwa. Stanowi męskie dominium i to nie tylko dlatego, iż rządzi nim Bóg Ojciec. Opowiadanie Sierpień przynosi opis późnego lata. Nieprzypadkowo narrator wielokrotnie posiłkował się epitetem tellurycznym, czyli związanym z ziemią zarządzaną przez bóstwa przyrody. Dominium fałszywej wiosny - przeciwnie - stanowiło zapomniane mieszkanie, a ona sama była efektem emanacji zdematerializowanego świata myśli - swoistego idealnego nieba odpoznawanego w procesie anamnezy, pozwalającej przywołać zapomniane żywoty i zdarzenia. Termin „telluryczny” znajdował tu swój odpowiednik w słowie „lśnienie”, określającym sposób istnienia fałszywej wiosny. Warto przywołać Mirceę Eliadego:

Babiloński Anu wyraża także pojęcie nieba. Najwyższy Bóg indoeuropejski Dieus oznacza zarazem epifanię niebiańską i sacrum (por. sanskr. diw - „błyszczeć”, „dzień”, djaus - „niebo”, „dzień”; Djaus hinduski bóg nieba). Zeus, Jupiter zachowują jeszcze w swoich imionach wspomnienie sakralności niebiańskich ${ }^{22}$.

Kończąc wywód pełen uniesienia, narrator wprost mówi o niebiańskim zakorzenieniu przedstawianej wizji. Wśród dużej liczby wymienionych obiektów zainteresowań jest także „astralne ciasto na pograniczu ciała i ducha” (S 70).

Nie powinno zatem dziwić, że ojciec powie o sobie: „Byłem szczęśliwy [...]”, gdy tylko uzna prawdziwość czy też spełnienie się męskiej kreacji nieba, za którym tak długo tęsknił i które wspominał. Niestety, śniący, emanacyjny świat „fałszywej wiosny” to tylko „fatamorgana” - piękna, inspirująca, dająca pozór wypełnienia zdarzeń i żywotów. Świat Sklepów cynamonowych poddany jest jednak innej materialnej zasadzie. Dlatego trzeci fragment ostatniej części Traktatu o manekinach przypomina o nieszczęściu i cierpieniu.

\section{Ból osobności i nieszczęście materii}

Po osobliwej anamnezie, w której trakcie ojciec na moment osiagnnął idealny stan duchowego szczęścia, następuje bolesny powrót do świata materii, co pozwala pomyśleć o Schulzu jako o XX-wiecznym gnostyku. Renate Lachmann m.in. pisała: „Mimo zmian i zniekształceń, których Bruno Schulz dokonuje na swoich pre-tekstach, rozpoznawalna jest w nich zarówno folia gnostycka, jak i kabalistyczna”23.

M. Eli a d e, Sacrum, mit, historia. Wybór esejów. Wybór, wstęp M. Czerwińs ki. Przeł. A. Tat a r k i e w i c z. Wyd. 3. Warszawa 1993, s. 128. Warto zwrócić uwagę na dwa podrozdziały cytowanej książki: Sacrum niebieskie i bogowie uraniczni oraz Bóg daleki - to one poniekąd tłumaczą kształtowanie się systemów monoteistycznych z nadrzędną figurą boga ojca, którego atrybut stanowi porządek solarny i którego locum to dalekie niebo. Jest to bardzo istotny wymiar statuowania systemu patriarchalnego w porządku religijnym i zarazem ważny wątek w moich odczytaniach opowiadań Schulza (zob. ibidem, s. 125-132).

R. La chma nn, Demiurg i jego fantazmaty. Spekulacje wokót mitologii stworzenia w dziele Bru- 
Nierozłączny związek materialności i cierpienia, wyrażony choćby w zdaniu „Ile starej, mądrej męki jest w bejcowanych słojach, żyłach i fladrach naszych starych, zaufanych szaf" (S 70), daje się zauważyć także w analizowanym przeze mnie opowiadaniu. Aby pojać przesłanie zawarte w tych tezach gnostyckich $z$ ducha, pamiętać trzeba o dynamice całego wykładu ojca.

W poprzedzającym fragmencie czytamy słowa ojca na temat szczęścia anamnezy i astralnego ciasta, proponującego alternatywną, męską formułę kreacji i życie oparte na idei wspomnienia i logosu (S 69-70). Ten eudajmonistyczny „humus wspomnień" na koniec zostaje zestawiony z materią par excellence, która - nie wątpię w to - myślana jest w greckim duchu jako üß $\eta$. To, że Jakub mówi o meblach, czyli obiektach zbudowanych z drewna, świadczy, że nazywa wprost rzeczy wykonane $z$ üA $\eta$. Warto przypomnieć, że pierwotnie filozoficzne pojęcie materii oznaczało po prostu drewno do budowy jakiegoś przedmiotu ${ }^{24}$. Zapewne nieprzypadkowo twory drewniane, do których należy manekin będący „kobiecym molochem” (S 58), wystawione zostają na cierpienie. $Z$ tego samego powodu - w końcówce wykładu Jakuba powraca temat przemocy wywieranej przez instancję formotwórcza, w tra-

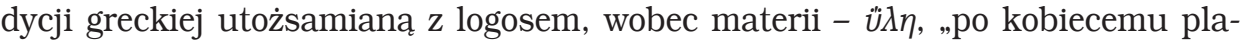
stycznej”. Czym jest jednak dla Schulza pełnia cierpienia ï^ $\eta$, traktowana po chrześcijańsku jako stan ukrzyżowania ${ }^{25}$ ? Materią cierpienia - proszę wybaczyć ów pleonazm - nie jest tylko sama materialność, lecz raczej efekt, czyli ukształtowanie osobowości w oparciu o samą materię: „Straszliwe transplantacje obcych i nienawidzacych się ras drzewa, skucie ich w jedną nieszczęśliwą osobowość" (S 70). Chodzi o kreację form złożonych wyłącznie z tego, co materialne. Cierpienie zatem nie wynika $z$ faktu materialności, jak chcieliby tego gnostycy, lecz z faktu nadłożenia naddatku ponad ową żywiołową i pierwotną materialność. Owym naddatkiem jest formotwórcza idea logosu, prowadząca w konsekwencji do ukonstytuowania nieszczęsnej osobowości, zindywidualizowanej sfery, którą w odniesieniu do człowieka należałoby nazwać samoświadomością własnego ,ja”. Włodzimierz Bolecki sugeruje, że owa opozycja (forma-materia, ,ja”-wielość) wywiedziona została przez Schulza z wczesnej myśli Nietzschego. Badacz stwierdza: „nietzscheański rodowód ma Schulzowskie przeciwstawienie dwóch sfer: pozaracjonalnego żywiołu oraz intelektu" ${ }^{26}$. Jest to zupełne odwrócenie ojcowskich założeń. Początkowo dokonuje się apoteoza wspominania i nostalgii, lecz w końcowej oracji w obrazie ojca także dokonała się zmiana, którą łączy homologiczna relacja $z$ dynamiką wykładu Jakuba. Józef tak to opisuje: „Twarz mego ojca, gdy to mówił, rozeszła się zamyślona liniatura zmarszczek, stała się podobna do sęków i słojów starej deski, z której

nona Schulza. Przeł. J. B a lb i er z. Weryfikacja przekł. P. La ch ma n n. „Teksty Drugie” 1999, nr 6, s. 104.

24 Zob. Materia. Hasło w: Słownik grecko-polski, t. 3, s. 391: „Üג - 1. Las, obszar lesisty, 2. Ścięte drzewo, bierwiona. 3. Materiał, z którego coś się robi. 4. Filozof. materia, Arist. To, co powstaje i ulega zniszczeniu. U późnych filozofów przew. opp. do pierwiastka duchowego i tworzącego".

25 Zob. S 70: „Kto wie - mówił - ile jest cierpiących, okaleczonych, fragmentarycznych postaci życia, jak sztucznie sklecone, gwoździami na gwałt zbite życie szaf i stołów, ukrzyżowanego drzewa, cichych męczenników okrutnej pomysłowości ludzkiej”.

26 W. B ole c ki, Principium individuationis. Motywy nietzscheańskie $w$ twórczości Brunona Schulza. „Teksty Drugie” 2003, nr 5, s. 24. 
zheblowano wspomnienia" (S 70). Ostateczny kres przedstawianej przez Jakuba wizji, jego powracająca amnezja, wydaje się ostatnim ogniwem z trzeciej części traktatu, gdzie po tezie na temat "generatio aequivoca" pojawiła się funkcjonująca na prawach antytezy wizja astralnego szczęścia, po której ojciec traci swą duchową, męską moc, wyzbywa się wspomnień (ergo: mocy anamnezy) i staje się materialnym obiektem par excellence - starą deską.

Jest to wymowny dowód porażki męskiego formotwórczego, niematerialnego logosu. Wszystko powraca do stanu pierwotnej materialności. Finał wywodu ojca spięty zostaje jedną klamrą z pierwszą częścią traktatu. Chwali się w nim materię lampę meluzynę zrobioną $\mathrm{z}$ ciała kochanki, kiszkę hegarową, w którą przeobraził się brat Jakuba. Te obiekty pozbawione osobowości, principium individuationis, choć wciąż żywe, o czym świadczy błonka śliny na lampie, są też pozbawione cech szczególnych. Z punktu widzenia tradycyjnej metafizyki jest to największe nieszczęście, jakie mogło spotkać kochankę i brata Jakuba. Odebrano im prawo do biografii i określenia osobowości: „Co za rozczarowanie dla rodziców [...], co za rozwianie wszystkich nadziei wiązanych z obiecującym młodzieńcem!” (S 71). Równocześnie sugestia ojca dotycząca stanu rodziców po przemianie syna i brata w zwój rurek gumowych pokazuje, że Jakub mówi także o „rozczarowaniu dla rodziców” i „dezorientacji dla ich uczuć” (S 71) jako o wyniku przemiany w czystą materię, pozbawiona principium individuationis, oznaczająca powrót do stanu czystej materii. Wszak budowanie osobowości paradoksalnie podmiotowej - o czym wspominał wcześniej ojciec - to położenie nacechowane niebywałym cierpieniem, zestawionym nawet $\mathrm{z}$ ukrzyżowaniem. Redukcja osobowego istnienia do formy manekina czy rury stanowić może wprawdzie akt wyzwolenia, pod warunkiem ujęcia w nawias tradycyjnej ontologii $z$ jej apoteozą formy, rozumianej w sposób arystotelesowski. O ile w pierwszej części Traktatu o manekinach ojciec dokonywał apologii sadyzmu i snuł wizję narzucania przemocą nowych form plastycznej, kobiecej materii, o tyle w zakończeniu, mówiąc - wydawałoby się - o tym samym, znacząco zmienił wartościowanie i afektywny odbiór takiego sposobu istnienia. Miejsce pochwały przemocy zajęło teraz współczucie dla osobowego bytu, który w stanie czystej materialności, czystego $\zeta \omega \eta \dot{~ b e z ~ b i o g r a f i i ~ o s i a g a ~ w y z w o l e n i e ~}{ }^{27}$. Kobiece mięso okazuje się ratunkiem przed zbyt skomplikowanymi osobnikami, uformowanymi w porządku logosu. Ten triumf kobiecego prawa dokonuje się choćby w końcowej scenie odczytu, gdy trzy kobiety wypędzaja męskiego uzurpatora: „Ojciec stropił się, zamilkł i zaczął, pełen przerażenia, cofać się tyłem przed kiwającym się palcem Adeli” (S 71). Fantazje ojca powracaja zatem do punktu wyjścia, jego pozycja zaś po raz kolejny odpowiada położeniu banity, dla którego nie ma miejsca w kobiecym świecie. Dorosły mężczyzna ponownie znika, a następne opowiadanie przedstawia raz jeszcze żeński świat bez ojców. Za to ze szczęśliwymi dziećmi i zwierzętami. O tym traktuje kolejny tekst Sklepów cynamonowych, zatytułowany Nemrod, ale to już temat innej historii.

27 Tak ową opozycję definiuje Markowski (op. cit., s. 32): „Dzoe to życie niezindywidualizowane, biologiczne w sensie ścisłym, organiczne, nad którym nie całkiem albo w ogóle nie panujemy, bo nie my je sobie nadaliśmy, bios natomiast to życie wpisane w jednostkową biografię, przepuszczone przez jednostkowe filtry zakorzenione w kulturze". 


\section{Abstract \\ MARCIN CAŁBECKI University of Gdańsk \\ ORCID: 0000-0001-5117-2062}

\section{EITHER WORD OR BODY CREATIVE DIALECTICS IN THE THIRD PART OF BRUNO SCHULZ'S “TRAKTAT O MANEKINACH” (“TREATISE ON MANNEQUINS")}

The article is an interpretation of the third part of Bruno Schulz's Traktat o manekinach (Treatise on Mannequins). Canonical text reading was performed, employing the anthropological tools that allow for the context of gender, and the study particularly describes the matter of maternalistic and paternalistic order rivalry. Special meaning is given here to the issue of competition which refers to male and female creative potential. The part of Traktat o manekinach (Treatise on Mannequins) subtitled Dokonczenie (Completion) sketches a vision of male creation that realises with abstract civilisation tools and with a creative word as its token. It is the order that in Schulz's texts enters into conflict with the female formula of creation effectuated by materiality supplemented by life element—-the body's dominium. 